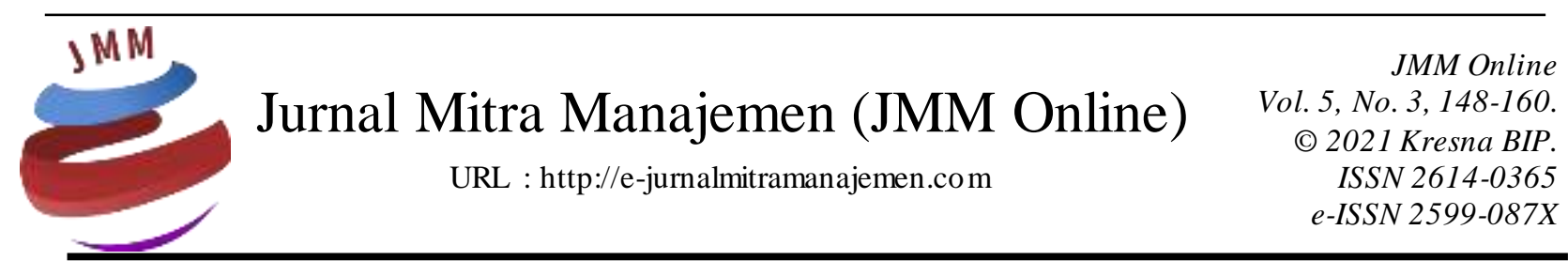

\title{
ANALISIS INOVASI PRODUK TERHADAP HARGA JUAL GARAM PADA PT GARSINDO ANUGERAH SEJAHTERA GRESIK
}

\author{
Yohannes Sugiarto, Woro Utari, C. Sri Hartati \\ Universitas Wijaya Putra Surabaya
}

INFORMASI ARTIKEL

Dikirim : 29 Maret 2021

Revisi pertama : 05 April 2021

Diterima : 10 April 2021

Tersedia online : 15 April 2021

Kata Kunci: Inovasi Produk, Harga Jual, Garam

Email : sugiarto.yohannes@yahoo.com

\section{ABSTRAK}

Tujuan penelitian ini adalah untuk mendesk ripsikan inovasi produk harga jual garam produk PT Garsindo Anugerah Sejahtera; untuk menganalisis inovasi produk dengan harga jual garam produk PT Garsindo Anugerah Sejahtera; untuk menentukan strategi inovasi produk dengan harga jual garam PT Garsindo Anugerah Sejahtera jangka menengah dan jangka panjang dalam menghadapi persaingan ke depan.

Jenis penelitian ini adalah deskriptif dengan pendekatan kualitatif. Sebanyak lima informan menjadi sumber pengumpulan data dalam penelitian ini. Penelitian ini dilakukan di PT Garsindo Anugerah Sejahtera, Gresik, Jawa Timur. Penelitian dilakukan secara semi-terstruktur dengan wawancara mendalam (in-depth interview).

Hasil penelitian menunjukkan bahwa inovasi produk terbukti mampu memperkuat produk perusahaan yang terungkap dari peningkatan daya saing produk-produk yang dijual oleh perusahaan di pasar domestik, bahkan sebagian sudah mulai bisa diekspor ke Jepang. Inovasi produk mampu meningkatkan harga jual barang menjadi lebih tinggi. Bahkan, inovasi ini bisa menciptakan barang setara dengan garam impor yang dipergunakan sebagian besar perusahaan-perusahaan di Indonesia. Inovasi produk yang kuat mampu memperluas pangsa pasar dan memudahkan para distributor untuk memasarkan produk-produk yang diciptakan oleh perusahaan. Inovasi produk juga menunjukkan keterkaitan antara branding dan inovasi terhadap peningkatkan penjualan garam. 


\section{PENDAHULUAN \\ Latar Belakang}

Bisnis garam terus mengalami perkembangan dengan pesat. Industri pegaraman terus melakukan inovasi dalam memproduksi garam, mereka (industri) bergerak untuk mengembangkan garam. PT Garsindo Anugerah Sejahtera tidak mau ketinggalan, perusahaan lokal yang berkantor di Gresik Jawa Timur ini juga melakukan inovasi dalam mengembangkan produksi garam.

Salah satu inovasi yang dilakukan PT Garsindo adalah memproduksi garam lokal setara garam impor. Salah satu produk yang menjadi tren di masyarakat bermerk 'Garam Ibu Bijak'. Inovasi garam ini dilakukan sebagai upaya membantu pemerintah untuk memenuhi target swasembada garam nasional yang telah dicanangkan.

Seorang pengamat tentang garam, Krisnayana Yahya, dalam wawancara dengan media online Realita.co, menyatakan, tahun 2030, pemerintah pusat mentargetkan swasembada garam nasional. Namun, target pada tahun 2030 tidak akan tercapai tanpa upaya di 2013, 2014, 2015, dan seterusnya. Dari statemen ini menggambarkan supaya semua pihak ikut terlibat aktif bersama pemerintah dalam mewujudkan produksi garam lokal sebagai swasembada garam nasional.

Keinginan pemerintah untuk swasembada garam nasional ini tidak akan terwujud jika tidak ada dukungan dari semua pihak, termasuk industri garam di Indonesia. Untuk itu, PT Garsindo Anugerah Sejahtera ikut aktif dalam mendukung cita-cita luhur pemerintah mensukseskan swasembada garam nasional.

PT Garsindo tidak hanya berwacana, inovasi dalam produksi telah dilakukan dengan memanfaatkan garam lokal. Dengan melakukan berbagai uji coba, PT Garsindo mampu memproduksi garam lokal mirip dengan impor. Produksi garam ini telah berwujud dengan berbagai merek, salah satunya 'Garam Ibu Bijak'.

Merk Garam Ibu Bijak ini diproduksi untuk memenuhi kebutuhan masyarakat secara langsung. Selain itu, PT Garsindo juga memproduksi garam untuk kebutuhan industri, bahkan terbaru menemukan cara produksi garam yang dipergunakan untuk SPA. Dari berbagai inovasi ini, pemerintah memberikan apresiasi dengan menjadikan industri PT Garsindo sebagai percontohan perusahaan lokal yang mampu memproduksi garam lokal menjadi sekualitas garam impor.

Fenomena gap (kesenjangan fenomena) kebutuhan garam di Indonesia dengan kemampuan produksi seluruh produsen garam secara nasional itu antara lain diungkapkan Safri Burhanuddin, Deputi Bidang Koordinasi Sumber Daya Maritim, Kementerian Koordinator Bidang Kemaritiman dan Investasi dalam webinar yang digelar Forum Diskusi Ekonomi Politik (FDEP), Kamis, 3 Desember 2020 (https://industri.kontan.co.id/news/kebutuhan-industri-tinggi-pemerintah-genjot-

produksi-garam-lokal). Menurut Safri Burhanuddin, pemerintah terus meningkatkan produksi garam lokal dan sekaligus meningkatkan kualitas. Upaya peningkatan produksi untuk memenuhi kebutuhan garam industri di Indonesia. Saat ini kebutuhan terus meningkat seiring dengan pertumbuhan industri di Indonesia.

Terutama kebutuhan garam industri masih menjadi masalah. Hal ini berbeda dari kebutuhan garam konsumsi yang sudah tidak banyak masalah. Dari data yang dipaparkan Safri Burhanuddin diketahui bahwa produksi garam pada tahun 2020 diprediksi sebesar 1,5 juta ton. Sementara kebutuhan garam pada tahun yang sama 
sudah mencapai sebanyak 4,46 juta ton. Selain kapasitas produksi yang masih dibawah angka kebutuhan, kualitas garam rakyat juga masih menjadi masalah dan tidak sesuai dengan kebutuhan industri. Sebagian besar produksi garam rakyat berada pada kualitas dua. Sehingga untuk memenuhi kebutuhan industri terpaksa dilakukan impor garam. Pemerintah Indonesia mendorong program washing plant untuk meningkatkan kualitas garam.

Studi emperik mengenai produksi garam juga memunculkan kesenjangan penelitian dikemukakan sejumlah peneliti. Antara lain penelitian oleh Arif Mustafa (2016), Ihsanudin et al. (2016), Jason Trikobery et al. (2017), Putu Sri Diana Wedari dan I Wayan Sukadana (2020), dan Yosephina Margaretha Jawa Batafor (2020) secara garis besar mengungkapkan kapasitas produksi garam baik garam rakyat maupun garam untuk industri. Ketidakseimbangan kapasitas produksi garam dengan kebutuhan secara nasional mendorong pemerintah untuk mengeluarkan regulasi keran impor. Sebagian penelitian lainnya menyoroti tentang kinerja finansial dan rata-rata menunjukkan hasil usaha tambak atau usaha garam memberikan keuntungan yang baik karena kebutuhan terus meningkat. Namun dari penelitian-penelitian itu menimbulkan research gap (kesenjangan penelitian) karena belum mengungkapkan perlunya inovasi produk dalam penguatan usaha garam dan meningkatkan penjualan.

Berdasar uraian latar belakang masalah dan adanya kesenjangan fenomena serta kesenjangan dengan penelitian-penelitian emperik sebelumnya, maka peneliti tertarik mengadakan penelitian lanjutan dengan judul "Analisis Inovasi Produk Terhadap Harga Jual Garam Pada PT Garsindo Anugerah Sejahtera, Gresik, Jawa Timur". Agar penelitian sesuai dengan hasil yang ingin dicapai maka peneliti membuat rumusan masalah dan tujuan penelitian sebagaimana terungkap dibawah ini.

\section{Rumusan Masalah}

1. Bagaimana deskripsi strategi inovasi produk, harga jual garam produk PT Garsindo Anugerah Sejahtera?

2. Bagaimana keterkaitan inovasi produk dengan harga jual garam produk PT Garsindo Anugerah Sejahtera?

3. Bagaimana strategi inovasi produk dengan harga jual garam PT Garsindo Anugerah Sejahtera untuk jangka menengah dan jangka panjang dalam menghadapi persaingan ke depan?

\section{Tujuan Penelitian}

Peneliti melakukan riset terhadap perkembangan garam yang dikelola PT Garsindo Anugerah Sejahtera. Tujuan yang ingin dicapai adalah:

1. Untuk mendeskripsikan inovasi produk harga jual garam produk PT Garsindo Anugerah Sejahtera.

2. Untuk menganalisis inovasi produk dengan harga jual garam produk PT Garsindo Anugerah Sejahtera.

3. Untuk menentukan strategi inovasi produk dengan harga jual garam PT Garsindo Anugerah Sejahtera jangka menengah dan jangka panjang dalam menghadapi persaingan kedepan 


\section{KAJIAN PUSTAKA \\ Inovasi}

Kegiatan inovasi adalah bagaimana melakukan sebuah kegiatan yang bisa meningkatkan nilai (added value) dan keunggulan dari kondisi saat ini. Cara-cara yang bisa dilakukan Antara lain dengan cara menciptakan pengembangan yang berbeda dari produk atau jasa yang sudah ada di pasar saat ini, atau menciptakan produk atau jasa yang sekiranya dapat menciptakan potensi pasar yang baru (Dhewanto et al., 2015).

Thornhill (2006) dalam Rosli \& Sidek (2013) mendefinisikan inovasi sebagai suatu proses penciptaan gagasan, pengembangan dari suatu keterbaruan, dan pengenalan suatu produk baru, proses atau pelayanan kepada masyarakat. Selain itu, Pearce \& Pearson (2013) juga berpendapat inovasi merupakan komersialisasi awal penemuan dengan menghasilkan dan menjual suatu produk, jasa, atau proses baru. Menurut Sukmadi (2016), inovasi berarti suatu ide, produk, informasi teknologi, kelembagaan, perilaku, nilai-nilai, dan praktik-praktik baru yang belum banyak diketahui, diterima, dan digunakan atau diterapkan oleh sebagian besar warga masyarakat dalam suatu lokalitas tertentu, yang dapat digunakan atau mendorong terjadinya perubahan-perubahan di segala aspek kehidupan masyarakat.

\section{Produk}

Kotler dan Armstrong (2016) menyebutkan, product is anything that can be offered to a market for attention, acquisition, use, or consumption that might satisfy a want or need. Artinya bahwa produk merupakan sesuatu yang bisa ditawarkan ke pasar untuk diperhatikan, dimiliki, digunakan, dikonsumsi yang bisa memuaskan keinginan atau kebutuhan. Produk dikatakan baik apabila produk tersebut dapat memenuhi kebutuhan pasar. Perkembangan penjualan produk yang tidak memenuhi kebutuhan dan keinginan pembeli, tidak dapat dibantu dengan strategi promosi penjualan yang efektif sekalipun. Karena tidak mampu membentuk, merubah produk tersebut menjadi sesuai dengan kebutuhan yang diharapkan pembeli. Produk adalah bentuk fisik barang yang ditawarkan dengan seperangkat citra (image) dan jasa (service) yang digunakan untuk memuaskan kebutuhan.

Oleh karena itu, pengertian perusahaan tentang hakekat produk di mata pembeli adalah penting, konsumen tidak semata-mata membeli atribut produk secara fisik tetapi juga manfaat-manfaat yang dapat diperoleh dari produk tersebut. Produk adalah seperangkat atribut baik berwujud maupun tidak berwujud termasuk di dalamnya warna, harga, nama baik produk, nama baik toko yang menjual (pengecer) dan pelayanan pabrik serta pelayanan pengecer yang diterima oleh pembeli guna memuaskan kebutuhan dan keinginannya. Sedangkan Fandy Tjiptono (2016) mendefinisikan produk sebagai segala sesuatu yang dapat ditawarkan produsen untuk diperhatikan, diminta, dicari, dibeli, digunakan, dikonsumsi pasar yang bersangkutan".

\section{Harga Jual}

Oentoro (2012) dalam Sudaryono (2016) mengungkapkan harga adalah suatu nilai tukar yang dapat disamakan dengan uang atau barang lain untuk manfaat yang diperoleh dari suatu barang atau jasa bagi seseorang atau kelompok pada waktu tertentu. Menurut Rudianto (2013), harga jual merupakan salah satu faktor yang sangat 
berpengaruh terhadap perusahaan, yaitu tingkat pendapatan yang diperoleh perusahaan dan perkembangan operasional perusahaan. Dalam penetapan harga jual perlu dipertimbangkan yang mendalam dan teliti guna memperoleh harga jual yang benarbenar sesuai dengan keinginan dan tujuan perusahaan. Keputusan harga jual merupakan keputusan yang sulit, karena faktor-faktor yang mempengaruhi, baik faktor intern maupun ekstern.

Menurut Harman Malau (2017:126) faktor-faktor yang dapat mempengaruhi harga di pasar adalah biaya produksi. Biaya produksi adalah biaya yang dikeluarkan untuk melakukan proses produksi. Biaya produksi terdiri dari biaya bahan baku yaitu biaya yang berkaitan dengan bahan langsung dalam melakukan produksi, biaya tenaga kerja langsung yaitu tenaga kerja yang terlibat langsung dengan proses produksi contohnya upah, dan overhead pabrik yaitu biaya selain bahan langsung dan tenaga kerja langsung contohnya penyusutan mesin dan sewa.

\section{METODE PENELITIAN}

\section{Jenis dan Pendekatan Penelitian}

Jenis penelitian ini adalah deskriptif yaitu mengumpulkan data sebanyakbanyaknya mengenai faktor-faktor yang menjadi fokus perhatian peneliti. Penelitian ini menggunakan pendekatan kualitatif. Sugiyono (2017) menyatakan metode penelitian merupakan cara ilmiah untuk mendapatkan data dengan tujuan dan kegunaan tertentu.

\section{Lokasi dan Subyek Penelitian}

Penelitian ini bertempat di PT Garsindo Anugerah Sejahtera, Jalan Mayjen Sungkono Gg 10 B No 6a, Segoromadu, Dusun Gunung Willis, Gresik Jawa Timur. Terdapat lima informan yang menjadi sumber data dalam penelitian ini, (X) Direktur Utama, (Y) Direktur Marketing, (ZI) MN-HRD, (A) Manajer Operasional, dan (B) Marketing.

\section{Metode Pengumpulan Data}

1. Wawancara Mendalam (In-depth Interview), Menurut Sugiyono (2017), wawancara merupakan pertemuan dua orang untuk bertukar informasi dan ide melalui tanya jawab, sehingga dapat dikonstruksikan makna dalam suatu topik tertentu.

2. Observasi, Sugiyono (2017) mengemukakan, observasi merupakan suatu proses yang kompleks, suatu proses yang tersusun dari berbagai proses biologis dan psikologis.

3. Dokumentasi, Menurut Sugiyono (2017), teknik dokumentasi merupakan catatan peristiwa yang sudah berlalu.

\section{Teknik Analisis Data}

Analisis data yang digunakan dalam penelitian ini menggunakan langkahlangkah dalam merumuskan strategi samudra biru atau lebih populer dengan istilahnya dalam Bahasa Inggris, Blue Ocean Strategy, adalah strategi yang menantang perusahaan untuk keluar dari samudra merah, persaingan berdarah dengan cara 
menciptakan ruang pasar yang belum ada pesaingnya, sehingga kata kompetisi pun menjadi tidak relevan. Dalam bagian ini peneliti menggunakan tahapan-tahapan dari strategi samudra biru. Alat analisis ini digunakan untuk menggambarkan perbandingan antara kedua strategi yang berbeda dan saling bertolak belakang. Secara garis besar, peneliti menggunakan 3 alat analisis utama yaitu Kanvas Strategi, Skema ERRC (Eliminate, Reduce, Raise, Create) dan Menjalankan Rangkaian Strategis Secara Benar

\section{HASIL PENELITIAN DAN PEMBAHASAN \\ Hasil Penelitian \\ Fokus Inovasi Produk}

Fokus inovasi produk mencakup beberapa pertanyaan yang berkaitan dengan upaya-upaya menjaga keberlangsungan produksi dan pengembangan jenis produk supaya garam yang diproduksi perusahaan bisa terus mampu bertahan dan memenangkan persaingan di pasar. Apalagi, garam milik PT Garsindo Anugerah Sejahtera memproduksi garam lokal menjadi setara garam impor.

Hasil dari wawancara Y, Z, dan A menyebutkan, untuk menjaga perusahaan menjadi lebih baik, perusahaan melakukan inovasi produk, mengikuti permintaan atau menyediakan produk yang akan menjadi permintaan. Selain itu, perusahaan juga mencari garam dari petani dengan harga murah, supaya harga jual mampu bersaing dengan kompetitor. Tidak hanya itu, perusahaan juga menjaga eksistensi garam dan meningkatkan kualitas produk di masyarakat.

Hasil wawancara Y, Z, dan A ditemukan, PT Garsindo mengembangkan garam SPA dan garam yramid. Segmentasinya untuk garam SPA dipergunakan ke salon dan kebutuhan kecantikan, sedangkan garam yramid untuk keperluan souvenir atau keperluan aesthetic karena bentuknya yang unik dan nilainya tinggi. Garsindo juga mengembangkan produk garam dengan kemasan premium yang dipasarkan lewat jalur online melalui campaign - campaign dan endorsement sehingga produk garam premium bisa masuk ke segmen menengah ke atas yang memiliki nilai jual tinggi. Strategi inovasi lain yang dilakukan adalah mengolah kembali air brine bekas cucian garam menjadi garam bahan baku. Bahkan, perusahaan ini juga membentuk PT (Perusahaan) baru untuk mengembangkan dan menginovasi garam.

Hasil wawancara Y, Z, dan A ditemukan, tahapan untuk mengolah garam menjadi berharga sangat banyak. Bahan mentah garam kemudian ditambahkan nilainilai tertentu, kemudian berubah wujud menjadi garam SPA yang dicampuri dengan pewangi. Menciptakan garam piramid juga menjadi terobosan untuk dijadikan oleholeh. Inovasi ini menjadikan nilai tinggi. Dari produksi ini nantinya dilakukan penjualan melalui distributor kemudian ke konsumen. Banyak pilihan garam yang dikeluarkan perusahaan, ada sekitar 19 merk yang dimiliki sebagai upaya memberikan penawaran kepada konsumen.

Hasil wawancara Y, Z, dan A ditemukan, faktor yang mempengaruhi inovasi karena ada permintaan, bisa juga karena melihat kompetitor yang lebih dulu berinovasi. Kemudian melakukan proses ATM yaitu Amati, Tiru, Modifikasi. Dari faktor-faktor tersebut muncul produk-produk yang dijual, mulai bubuk merica putih, bubuk merica hitam, bubuk bawang puth dan bubuk cabai, juga akan menjual garam 
rendah natrium. Produk-produk dikeluarkan dengan tujuan untuk menerapkan strategi baru perusahaan karena ada peluang yang dimanfaatkan.

Hasil wawancara Y, dan Z, A menyebutkan, inovasi terbaru yang dimiliki perusahaan Garsindo adalah pembuatan garam konsumsi beryodium dengan kemasan 5 kilogram (kg) dan penambahan izin merek Arkipala untuk persiapan ekspor. Membuat garam piramid dan mendirikan perusahaan khusus untuk memproduksi garam piramid.

Hasil wawancara Y, Z, dan A dapat disimpulkan kalau perusahaan dalam memanajemen permintaan barang lebih fleksibel. Perusahaan bisa menyesuaikan permintaan customer. Selain itu, untuk meyakinkan customer, perusahaan menegaskan kemasan yang dipergunakan tersertifikasi ISO 22000 yaitu Food Safety. Sehingga terjamin mutu serta kualitas produksi garam.

Hasil wawancara Y mengenai strategi distribusi ke distributor untuk menjaga penjualan barang dilakukan dengan memberikan bonus. Kemudian menjadikan konsumen sebagai partner bukan sebagai pembeli biasa.

Hasil wawancara $\mathrm{Y}$, perusahaan sangat menjaga stok untuk bisa menguasai pasar. perusahaan menilai, persaingan yang paling ketat karena ada garam impor. Untuk itu, sistem distribusi yang diterapkan tertata rapi.

Hasil wawancara $\mathrm{X}, \mathrm{B}$, dan $\mathrm{X}$ bisa diketahui, perusahaan hanya menetapkan satu distributor dalam setiap daerah. Mereka menjadi partner dalam pengembangan bisnis. Perusahaan tidak akan mengizinkan orang lain masuk sebagai distributor, kalau ada masyarakat yang ingin bergabung menjadi distributor, mereka tetap berada dibawah distributor pertama. Cara ini menjadikan distributor sangat loyal kepada perusahaan.

\section{Fokus Harga Jual}

Menurut Rudianto (2013), harga jual merupakan salah satu faktor yang sangat berpengaruh terhadap perusahaan, yaitu tingkat pendapatan yang diperoleh perusahaan dan perkembangan operasional perusahaan. Untuk mengetahui mengenai harga jual produk garam dan pendapatan yang diperoleh perusahaan. Hasil wawancara $\mathrm{X}$ dan $\mathrm{Y}$, produksi yang dikeluarkan perusahaan rata-rata setiap hari mencapai 100 ton. Untuk menjaga produksi, perusahaan mengeluarkan jenis-jenis garam dan harganya. Kemudian penetapan harga jual juga menjadi pertimbangan untuk bisa bersaing dengan kompetitor. Inovasi garam juga mampu menjaga harga garam menjadi lebih baik.

\section{Pembahasan}

\section{Fokus Inovasi Produk}

Strategi inovasi produksi dengan mengolah kembali air brine (air tua) bekas cucian garam menjadi garam bahan baku akan membuat harga menjadi sangat murah sehingga segmen kelas bawah bisa membeli namun dengan kualitas garam yang baik. Untuk meningkatkan kapasitas produksi air brine, perusahaan bahkan membuat PT yang baru untuk pabrik baru sebagai strategi untuk mempermudah pengelolaan bisnis yang terus berkembang

Selain inovasi mesin dan efisiensi kerja, perusahaan juga berinovasi dalam hal produk, dimana kami sekarang mengembangkan garam SPA dan garam piramid. 
Garam SPA untuk salon dan kebutuhan kecantikan, sedangkan garam piramid untuk keperluan souvenir atau keperluan aesthetic karena bentuknya yang unik dan nilainya tinggi. Perusahaan juga mengembangkan produk garam dengan kemasan premium yang dipasarkan lewat jalur online melalui kampanye-kampanye dan endorsement sehingga produk garam premium bisa masuk ke segmen menengah ke atas yang memiliki nilai jual tinggi. Pada lini bisnis ini perusahaan tidak bermain pada volume besar tetapi lebih ke profit.

Perusahaan juga membangun sistem yang bisa memberi nilai tambah (value added) pada produk. Bahan dasar tentu saja masih garam, tetapi ditambahkan nilainilai atau bahan-bahan tertentu yang berguna untuk menunjang agar garam yang dijual mempunyai nilai tambah yang dibutuhkan pasar. Sebagai contoh, garam SPA adalah garam yang diberi pewangi dan pewarna dengan rincian resep tertentu sehingga menjadi garam SPA yang banyak dicari di salon-salon maupun hotel. Lain lagi dengan garam piramid. Melalui cara pengolahan tertentu dari air laut dengan perhitungan yang matang agar bisa dipanen menjadi garam piramid yang memiliki nilai jual tinggi, terutama untuk pasar ekspor, seperti ke Jepang. Garam piramid semacam ini bisa menjadi souvenir karena bentuknya yang unik seperti piramid.

Perusahaan juga menempuh kerjasama berupa nota kesepahaman dengan perusahaan-perusahaan lain sehingga pemasaran produk garam bisa semakin meluas sebarannya. Strategi ini menjadi bagian dari pengenalan brand produk sekaligus agar diperoleh pelanggan-pelanggan baru. Serentak itu perusahaan mengupayakan diversifikasi produk-produk turunan dan mendapat izin edar dari pihak berwenang. Yang termasuk diversifikasi produk-produk turunan itu antara lain garam rendah natrium dan garam bumbu sebagai bagian dari upaya mendapatkan pangsa pasar yang baru. Ada beberapa produk yang dikembangkan antara lain garam konsumsi, garam industri, garam halus, garam kasar, garam kemasan dengan aneka merk.

Perusahaan membeli garam petani dengan harga yang pantas sesuai dengan harga pasar. Syaratnya adalah petani harus menjaga kualitas garam tetap baik sesuai dengan standar SNI 4435:2017 untuk persyaratan mutu garam bahan baku untuk garam konsumsi beryodium. Perusahaan juga memberikan edukasi agar petani bisa menghasilkan garam bahan baku berkualitas tinggi.

Hubungan dengan petani garam terus dijaga supaya bisnis garam terus bisa eksis, terus berlangsung. Untuk itu khususnya pada bisnis garam beryodium diterapkan strategi menjaga harga jual produk tetap stabil sehingga dapat berkompetisi dengan perusahaan produsen lainnya. Perusahaan berupaya untuk mendapatkan harga beli bahan baku garam dari petani dengan harga cukup murah. Selain itu juga memanfaatkan air brine (air tua) yang diolah kembali menjadi bahan baku garam dengan menggunakan rumah kaca dan teknologi centrifuge.

Inovasi yang dilakukan bukan hanya bagaimana berpikir tentang hasil produksi yang baru. Tetapi untuk bisa menghasilkan produk-produk yang inovatif juga dibutuhkan inovasi teknologi yang mendukung proses inovasi itu sendiri. Untuk itu perusahaan memutuskan untuk berinovasi dalam bidang mesin pengolahan, sehingga dengan bahan baku lokal, dihasilkan produk yang berkualitas dan mampu bersaing dengan produk-produk impor. 
Mengapa perusahaan melakukan inovasi produk karena banyak faktor, bisa karena ada permintaan konsumen atau karena pesiang sudah berinovasi terlebih dulu, lalu perusahaan melakukan proses ATM (Amati, Tiru, Modifikasi). Perusahaan juga mengantongi izin edar produk yang baru yaitu produk bubuk merica putih, bubuk merica hitam, bubuk cabai dan bubuk bawang putih. Sedangkan merek yang terdaftar resmi ada 19 merek. Inovasi terbaru yang sudah dilaksanakan dengan pembuatan garam konsumsi beryodium dengan kemasan $5 \mathrm{~kg}$ dan penambahan izin merek Arkipala untuk persiapan ekspor.

Strategi branding yang diusung oleh perusahaan dengan brand utama : IBU BIJAK, mempunyai kekuatan dampak psikologis yang sangat besar terhadap konsumsi garam produksi PT Garsindo Anugerah Sejahtera. Tren penjualan yang dari tahu ke tahun menunjukkan peningkatan dari sisi kinerja keuangan membuktikan bahwa pilihan brand utama sudah berada pada track yang tepat.

Kualitas produksi tetap diutamakan, baik itu permintaan untuk garam konsumsi maupun garam industri, baik garam dalam kemasan maupun karung. Standar penjaminan mutu menggunakan standar SNI dan juga sudah tersertifikasi ISO 2200 yaitu Food Safety. Kedua standar mutu tersebut menjadi jaminan kualitas garam produksi perusahaan dengan brand utama IBU BIJAK.

Meskipun pandemi Covid-19 masih berlangsung, permintaan terhadap produksi garam bervariasi, ada yang cenderung turun, ada yang stabil dan dalam beberapa kesempatan menunjukkan peningkatan. Realitas ini tentu menggembirakan mengingat pandemi Covid-19 mempunyai dampak yang luar biasa besar terhadap kegiatan masyarakat, khususnya yang berkaitan dengan tingkat konsumsi garam. Jika sebelum pandemi Covid-19, banyak kegiatan masyarakat yang berkaitan dengan konsumsi garam, seperti acara-acara pernikahan dan lainnya berlangsung besar-besaran, maka selama pancemi Covid-19 ini, sangat terbatas dan dibatasi oleh kebijakan pemerintah.

Pada titik-titik distribusi yang mengalami sedikit penurunan penjualan, perusahaan menerapkan strategi bisnis dengan menjaga agar stok produk dengan merek produksi perusahaan. Tujuannya agar produk garam perusahaan di pasaran tetap harus melimpah sebagai cara untuk bertahan dan tidak memberi kesempatan kepada merek-merek lain untuk memasuki pasar. Sedang dari sisi internal, produksi tetap harus berjalan stabil sesuai protokol kesehatan, tidak boleh sampai ada karyawan yang dirumahkan/diliburkan. Demikian juga terus diupayakan penelitian dan pengembangan produk garam yang bernilai jual tinggi, seperti garam rendah natrium, bumbu-bumbu masakan, garam piramida, dan lain-lain.

Strategi keunggulan kompetitif berkelanjutan (sustained competitive advantage) juga dikembangkan oleh perusahaan. Bersama-sama dengan praktik pemasaran yang terus dijalankan sampai dengan saat ini, perusahaan juga memformulasikan strategi untuk jangka menengah dan jangka panjang.

Pada formulasi strategi jangka menengah, perusahaan menyasar industri makanan ternak. Mengapa sektor industri makanan ternak merupakan peluang sangat besar karena dari hasil penelusuran, riset dan pengembangan, ditemukan data bahwa penggunaan garam untuk kebutuhan tersebut sangat besar sampai ribuan ton, dan garam yang dipakai bisa kasar dan halus. Perusahaan akan masuk ke sana untuk bersaing dan menguasai pemasok garam ke perusahaan-perusahaan tersebut. 
Sedangkan formulasi strategi jangka panjang, perusahaan akan meningkatkan penetrasi pasar garam piramid. Mengapa masuk ke pasar garam piramid karena tidak mudah, meskipun garam ini sudah ada di Bali dan diekspor ke Jepang. Garam piramid mempunyai harga jual tinggi, satu biji bisa mencapai $\mathrm{Rp}$ 5.000. Perusahaan terus melakukan riset di jenis garam piramid supaya bisa panen raya jenis garam piramid ini.

Strategi-strategi jangka menengah dan jangka panjang tersebut ditempuh perusahaan sebagai upaya untuk menciptakan keunggulan kompetitif berkelanjutan. Brand-brand yang diciptakan perusahaan dengan brand utama IBU BIJAK diharapkan bisa diterima pasar sehingga perusahaan mempunyai kekuatan bersaing dan menciptakan keunggulan kompetitif.

Strategi yang sudah dan sedang dilakukan perusahaan agar mampu menciptakan keunggulan kompetitif dalam menghadapi kompetitor antara lain dengan melakukan sejumlah terobosan berupa pemberian bonus kepada masyarakat. Pelanggan yang membeli garam dengan nilai tertentu akan diberi bonus emas atau motor untuk pelanggan-pelanggan lama. Strategi semacam ini memicu pembelian konsumen terhadap garam hasil produksi perusahaan.

Perusahaan selalu berupaya untuk menancapkan brand-brand produk garam yang diciptakan melalui promo-promo yang dilakukan di benak pelanggan melalui brand awareness. Apabila brand awareness pelanggan terhadap brand-brand produk garam perusahaan sudah melekat di benak konsumen maka akan tercipta brand equity. Dari kedua situasi tersebut diharapkan di benak konsumen kemudian terbentuk sikap dan perilaku untuk kembali membeli garam hasil produksi perusahaan. Perilaku pembelian berulang melalui pengalaman (experience) diyakini perusahaan mampu meningkatkan keunggulan kompetitif berkelanjutan.

Perusahaan juga menciptakan hubungan pelanggan (customer relationship) yang saling menghargai. Pembeli tidak diperlakukan sebagai orang asing, tetapi mereka adalah partner atau mitra perusahaan. Penciptaan hubungan pelanggan yang menempatkan pelanggan atau pembeli inilah yang mendorong perusahaan menyediakan hadiah-hadiah bagi pelanggan atau konsumen. Jadi perusahaan menjaga pelanggan dengan baik, dan sama-sama untung. Strategi ini berbeda dari strategi pesaing, yang seringkali menaikkan harga secara tiba-tiba hanya untuk mengeruk untung sesaat dengan memakai sistem beli putus.

Strategi branding dan promosi tidak hanya untuk memenangkan persaingan dengan garam produk-produk dalam negeri. Perusahaan berusaha membangun sistem produksi yang sangat terjaga sebagai upaya untuk mampu bersaing dengan garam impor. Perusahaan lebih memilih bekerja sama dengan petani garam dalam negeri, sehingga sangat berkepentingan untuk menangkal banjirnya garam impor, dengan cara atau program perluasan brand berupa penambahan hingga sekarang sudah ada 19 brand yang diciptakan dan dipromosikan oleh perusahaan.

Peningkatan kualitas produksi selain untuk bersaing dengan produk impor, juga berdampak pada perluasan pemasaran garam perusahaan. Garam hasil produk perusahaan sudah masuk ke perusahaan-perusahaan besar di bidang makanan dan minuman seperti Mayora, Wings, dan industri kecap yang ada di Indonesia. Perusahaan bertekad untuk menunjukkan kepada para pesaing bahwa garam lokal juga bisa bersaing dengan garam impor. Selain itu, perusahaan juga memberikan layanan 
yang baik dengan membangun hubungan dengan konsumen korporasi sebagai partner atau mitra bisnis, bukan sekadar bisnis transaksional jangka pendek. Khusus untuk garam SPA membidik pasar hotel, dan rencana ekspor ke Turki, Korea Selatan. Garam SPA untuk membidik pasar segmented, kelas premium.

Pada waktu yang bersamaan, perusahaan juga memantau pergerakan kompetitor sebagai bagian dari implementasi strategi pemasaran, khususnya ketika pesaing menerapkan strategi yang sama. Perusahaan diuntungkan oleh keputusan memulai implementasi terlebih dulu sehingga pesaing bisa dikatakan kalah start.

\section{Fokus Harga Jual}

Usaha-usaha keras perusahaan dari sisi aneka strategi branding dan pemasaran serta strategi produksi berdampak pada kinerja keuangan perusahaan. Dari tahun ke tahun sejak perusahaan beroperasi 4 Januari 2017, kinerja keuangan perusahaan terus menunjukkan tren positif.

Data kinerja keuangan dalam tiga tahun terakhir menunjukkan volume penjualan yang relatif stabil. Misalnya pada tahun 2018, perusahaan mampu membukukan angka penjualan lebih dari Rp 34 miliar. Tahun berikutnya (2019) terjadi sedikit penurunan angka penjualan menjadi sekitar Rp 26,5 miliar. Tetapi pada tahun 2020 terjadi lonjakan angka penjualan dan mampu mengembalikan ke posisi setara dengan angka penjualan pada tahun 2018, yaitu lebih dari Rp 34 miliar.

Yang menarik pada angka penjualan di tahun 2020 ketika dunia dilanda pandemic Covid-19 justru mengalami peningkatan yang signifikan apabila dibandingkan dengan angka penjualan pada tahun sebelumnya, tahun 2019. Peningkatan angka penjualan tentu merupakan hasil dari kerja keras pemasaran dan peningkatkan kualitas produk dengan serangkaian inovasi yang dilaksanakan oleh perusahaan.

Dari sisi angka penjualan sempat terjadi penurunan pada tahun 2019, namun apabila melihat angka-angka laba bersih yang berhasil dibukukan oleh perusahaan justru memperlihatkan tren yang terus meningkat. Pada tahun buku 2018 berhasil dicapai laba bersih Ro 993 juta lebih per tahun. Setahun kemudian laba bersih yang berhasil dibukukan perusahaan mencapai lebih dari Rp 1,2 miliar. Angka tahun 2019 itu meningkat lebih dari 100 persen pada tahun 2020 dengan berhasil membukukan laba bersih mencapai lebih dari Rp 3 miliar.

Dari data kinerja keuangan menunjukkan bahwa bisnis sektor garam, mulai dari garam konsumsi, garam industri hingga garam untuk kebutuhan-kebutuhan kecantikan dan souvenir merupakan bisnis yang menjanjikan. Meskipun tidak mengambil keuntungan dalam jumlah yang besar untuk per kilogramnya, perusahaan tetap mendapat manfaat yang besar. Dari data yang tersedia, perusahaan membeli dari tingkat petani garam sebesar Rp 600/kg dan menjual ke pasar di kisaran harga $\mathrm{Rp}$ 800/kg. Margin keuntungan sebesar Rp 200/kg tinggal dikalikan berapa ton dalam setahun untuk mendapatkan angka penjualan dan laba bersih setelah dipotong berbagai biaya yang memang harus dikeluarkan oleh perusahaan.

Harga garam tersebut belum termasuk produk-produk inovasi yang dilakukan oleh perusahan. Untuk garam hasil novasi dengan bentuk-bentuk yang berbeda, maka harga akan semakin tinggi, seperti garam SPA. Inovasi harus dilakukan di petani, tidak 
harus di pengusaha. Contohnya, membuat garam piramid, petani belajar ke pengusaha supaya bisa melakukan inovasi sendiri. Direktur Utama menyatakan, misalnya, perusahaan kemudian menjualnya secara ekspor bisa 12 ton, satu kontainer butuh 20 ton, berarti terjadi kekurangan sebanyak 8 ton, maka kekurangannya itu diambilkan dari petani yang sebelumnya diajari oleh perusahaan.

\section{KESIMPULAN DAN SARAN Kesimpulan}

Menjawab rumusan masalah dan berdasar hasil penelitian serta pembahasan hasil penelitian maka dapat diambil kesimpulan sebagai berikut:

1. Inovasi produk terbukti mampu memperkuat produk perusahaan yang terungkap dari peningkatan daya saing produk-produk yang dijual oleh perusahaan di pasar domestik, bahkan sebagian sudah mulai bisa diekspor ke Jepang.

2. Inovasi produk mampu meningkatkan harga jual barang menjadi lebih tinggi. Bahkan, inovasi ini bisa menciptakan barang setara dengan garam impor yang dipergunakan sebagian besar perusahaan-perusahaan di Indonesia.

3. Inovasi produk yang kuat mampu memperluas pangsa pasar dan memudahkan para distributor untuk memasarkan produk-produk yang diciptakan oleh perusahaan. Inovasi produk juga menunjukkan keterkaitan antara branding dan inovasi terhadap peningkatkan penjualan garam.

\section{Saran}

Beberapa saran bisa disajikan setelah melihat hasil penelitian dan kesimpulan sebagai berikut:

1. Perusahaan perlu lebih kreatif lagi menciptakan inovasi-inovasi yang dengan branding yang berorientasi pasar pada segmen kaum milenial supaya muncul kesan bahwa garam tidak hanya identik dengan ibu-ibu.

2. Perusahaan perlu memperkuat visi misi untuk semakin berkomitmen dan bangga dengan produk-produk yang berbahan baku 100 persen Indonesia, sehingga semakin meningkatkan kesejahteraan petani garam lokal. Selain itu juga untuk melindungi pasar domestik dari gempuran produk-produk gram impor, sehingga perusahaan bisa menjadi contoh bagi perusahaan-perusahaan lain.

3. Perusahaan harus menjadikan media sosial, internet, maupun media-media untuk mengenalkan produk-produk yang dimiliki.

\section{DAFTAR PUSTAKA}

Dhewanto, W., Indradewa, R., Ulfa, W. N., Rahmawati, S., Yoshanti, G., \& Lumanga, C. Z.(2015). Manajemen Inovasi untuk Usaha Kecil dan Mikro. Bandung: ALFABETA.

Fandy, Tjiptono. 2016. Service, Quality \& satisfaction. Yogyakarta. Andi.

Harman Malau. 2017. Manajemen Pemasaran. Bandung : Alfabeta.

Ihsannudin, Sukmo Pinujib, Subejo, Bertus Sumada Bangko. 2016. Strategi Pemberdayaan Ekonomi Petani Garam Melalui Pendayagunaan Aset Tanah Pegaraman. Economics Development Analysis Journal 5 (4) (2016). http $/ /$ journal.unnes.ac.id/sju/index.php/edaj. 
Jason Trikobery, Achmad Rizal, Nia Kurniawati, Zuzy Anna. 2017. Analisis Usaha Tambak Garam Di Desa Pengarengan Kecamatan Pangenan Kabupaten Cirebon. Jurnal Perikanan dan Kelautan Vol. VIII No. 2/Desember 2017 (168175).

Kontan.co.id. 2020. Kebutuhan industri tinggi, pemerintah genjot produksi garam lokal. https://industri.kontan.co.id/news/kebutuhan-industri-tinggi- pemerintahgenjot-produksi-garam-lokal, diakses 10 Februari 2020, pukul21.17 wib

Kotler, Philip and Gary Amstrong. 2016. Prinsip-prinsip Pemasaran. Edii13.Jilid 1. Jakarta:Erlangga

Mustafa, Arif. 2016. Strategi Pengembangan Usaha Garam Rakyat Di Kecamatan Kedung Kabupaten Jepara. Jurnal DISPROTEK Volume 7 No. 2 Juli 2016.

Pearce, J., \& Robinson, R. 2013. Strategic Management Planning for Domestic \& Global Competition. London: McGraw-Hill Education.

Putu Sri Diana Wedari Dan I Wayan Sukadana. 2020. Garam Industri Impor Sebagai Input Kunci Sektor Industri Pengguna Garam Dan Multiplier Efeknya Terhadap Perekonomian. E-Jurnal Ekonomi Pembangunan Universitas Udayana, Vol.9.No.5 Mei 2020.

Rosli, \& Sidek. 2013. The impact of Innovation On the Performance of Small and Medium Manufacturing Enterprises:Evidence from Malaysia. Entrepreneurship Vision 2020: Innovation, Development Sustainability, and Economic Growth 794-809.

Rudianto. 2013. Akuntansi Manajemen: Informasi Untuk Pengambilan Keputusan Manajemen, Jakarta: Grasindo,

Sudaryono. 2016. Manajemen Pemasaran Teori dan Implementasi. Yogyakarta: C.V. Andi Offset.

Sugiyono, 2017. Metode Penelitian Bisnis. Pendekatan Kuantitatif, Kualitatif, Kombinasi, dan RD. Bandung: Alfabeta.

Sukmadi. 2016. Inovasi \& Kewirausahaan. Bandung: Humaniora Utama Press.

Yosephina Margaretha Jawa Batafor. 2020. Identifikasi Permasalahan Produksi Garam Lokal Di Kabupaten Flores Timur. Jurnal Akuatika Indonesia. Vol. 5 No. 2/ September 2020. 